\title{
Empowering Love and Respect for Child Offenders through Therapeutic Jurisprudence: The Teen Courts Example
}

\author{
Lynne Marie Kohm ${ }^{1, *}$, Alison R. Haefner ${ }^{2}$ \\ ${ }^{1}$ John Brown McCarty Professor of Family Law, Regent University School of Law, USA \\ ${ }^{2}$ Juris Doctor (JD) Program, Regent University School of Law, USA
}

Copyright $\mathrm{O} 2016$ by authors, all rights reserved. Authors agree that this article remains permanently open access under the terms of the Creative Commons Attribution License 4.0 International License

\begin{abstract}
A fascinating trend is emerging in juvenile justice - teen courts. As peer-based forums appearing in pockets throughout the United States, these specialized courts for child offenders are designed to actively draw the child into his or her own criminal process, allowing "the law to work as a therapeutic agent."[1] We posit that the teen court process empowers children with respect from peers, family and community because of the therapeutic manner of administering justice on behalf of the child offender. This process becomes a therapeutic model when children's lives are changed by the beneficial involvement of their peers in their legal process. The experience of participating in their own justice and the justice of their peers seems to create a natural pathway to building a broader sense of personal responsibility, active citizenship, and a generally healthier future.
\end{abstract}

Keywords Juvenile Justice, Teen Courts, Personal Responsibility, Active Citizenship, Active Citizenship

\section{Introduction}

"The life of the law has not been logic: it has been experience. The felt necessities of the time, the prevalent moral and political theories, institutions of public policy, avowed or unconscious, even the prejudices which judges share with their fellow-men, have had a good deal more to do than the syllogism in determining the rules by which men should be governed." [2]

A juvenile justice system essentially rests on the tradition of the best interest of the child standard, and is applied to the extent that the child is not transferred to adult criminal courts but sought to be rehabilitated in a court designed to meet the needs of children.[3] Current juvenile justice systems, however, are in somewhat of a crisis. For example, for four decades the United States government has increased funding for incarcerating American youth, who are otherwise not a danger to public safety, in adult-like prisons.[4] This trend has perpetuated juvenile crime into a lifestyle, and placed juvenile offenders at grave risk for abuse and a criminal future. "Juvenile delinquency is of perpetual concern in the United States. In 2007, law enforcement agencies reported 2.18 million arrests of juveniles.... It is estimated that $\$ 14.4$ billion is spent annually on the federal, state and local juvenile justice systems." [5] Juvenile courts do not appear to be adequately handling juvenile crime, nor are they necessarily leaders in helping children in rehabilitation away from crime.[6] In fact, the focus of the system is retributive, whether by intent or by caveat.

Combating this problem, a fascinating trend is emerging in juvenile justice - teen courts. As peer-based forums appearing in pockets throughout the United States, these teen courts are designed to actively draw the child into his or her own criminal process. Allowing "the law to work as a therapeutic agent."[7] We posit that the teen court process empowers children with respect from peers, family and community because of the therapeutic manner of administering the law to the child offender.

While garnering the attention of researchers for some time, [8] much is still unknown about these teen disposition forums. Also sometimes referred to as a youth court, these courts are specialized community programs which accept, hear, try, and sentence mostly first time misdemeanor offense cases when the defendant is a child, most often between the ages of twelve and seventeen.[9] With professional guidance from adults, these diversion forums are quasi-courts organized by children, for children, with children acting as prosecutor, defense attorney, juror, bailiff and in some cases even judge.[10] Supported by the local community in schools, churches, treatment centers, or law schools, youth courts offer an alternative to traditional juvenile justice based on the notion that a jury of peers may more adequately administer justice in a way best for a 
child.[11] They seem to work because children operate largely in a framework of peer influence and respect. When that influence is positive, the result is positive as well.

This process becomes a therapeutic model when children's lives are changed by their interaction with the law toward a better sense of well-being. The experience of participating in their own justice and the justice of their peers seems to create a natural pathway to building a broader sense of personal responsibility, active citizenship, and a generally healthier future [12]. This article explores these notions in depth, with a focus on how therapeutic jurisprudence brings forth that much needed change in the administration of juvenile justice. Exploring and examining how teen courts are advanced in the model of therapeutic jurisprudence, this article examines the research and methodology of this new program of teen courts to determine whether and how a teen court forum can enhance and develop a child's decision-making process in the context of a reliable rule of law based on a jury of peers. These wonderfully rich opportunities for child offenders and other child participants are unique to the teen court process of juvenile justice and are essentially based on notions of therapeutic justice. They may provide an alternative that can positively contribute to the administration of justice to juvenile offenders.

\section{Therapeutic Jurisprudence \& Teen Courts}

The underlying problems of the juvenile justice system highlight the need for therapeutic jurisprudence and help to explain the rise of phenomenon like teen courts. The opportunity to intercept and redirect a child behaving criminally strikes at the heart of social science, creating a need for understanding the solutions to the problems facing juvenile justice today.

\section{A. American Juvenile Justice System: The Underlying Problem}

The failure of the American juvenile system to encourage rehabilitation and discourage a life characterized by crime sparked the foundation of teen courts.[13] For decades, the government has increasingly sent youths to adult-like prisons, "[perpetuating] juvenile crime into a lifestyle and [placing] juvenile offenders at grave risk for abuse and a criminal future."[14] The juvenile court was originally implemented to combat the problem of teen cases being tried in adult criminal court with the ultimate goal of rehabilitation and steering youth away from a life characterized by crime.[15] Today's juvenile court system, however, continues to produce high recidivism rates and other consequences such as mental, physical, and psychological problems in teens rather than addressing the underlying issues that lead to these circumstances.[16]

Reports estimate that 2.1 million youth are arrested each year, and, of those arrested, juvenile courts see 1.7 million cases.[17] While 57\% are given probation, almost 87,000 youths under 21 "are detained or confined in public and private detention centers, group homes, camps, ranches, and other correctional institutions." [18] The average cost per day for each youth to stay in those facilities is $\$ 240.99$, where "70 percent of adjudicated youth reside."[19] Studies show that the youth confined in these facilities may experience "overcrowding, physical and sexual violence, trauma, risk of suicide, and death."[20] Although national recidivism is difficult to measure from a lack of standardized measurements, youths who were released from state detention facilities had considerably higher rates of rearrest, averaging 55 percent.[21] Out of the 55 percent rearrested, 24 percent were re-incarcerated or re-confined.[22] Although the percentage of arrests has decreased by $50 \%$ since 2005 , there were estimated over 1 million arrests of children under 18 in 2014.[23] About two thirds of those arrested will be referred to the juvenile justice system for further processing.[24] In 2010, juvenile courts adjudicated almost 1.4 million delinquency cases, those cases an adult could be prosecuted for in criminal court.[25] While incarcerated and detained, youth in the juvenile justice system continue to experience problems academically, resulting in literacy concerns[26] and "academic achievement below the grade equivalent for their age."[27]

The underlying problem seems to be the system itself, and how its methods negatively affect child offenders.

\section{B. Teen Courts: Intercepting \& Redirection}

Intercepting and redirecting a child involved in a crime becomes a key objective for rehabilitative justice. Teen courts, peer-based forums designed to draw the child actively into his or her own criminal process through dynamic participation, serve to intercept certain juveniles from the traditional juvenile justice system in hopes of preventing further interaction with the system and its harmful emotional, mental, and physical consequences. Teen courts function by allowing a youth to take an active role in his or her own criminal procedures.[28] Teen offenders are often referred to teen, or youth courts through many different avenues, from the school counselors or principals or directly from law enforcement officials, juvenile courts, prosecutors, or judges.[29] To participate in most teen court programs a child offender must take responsibility for his or her crime, in the presence of a jury made up of other teens; this effectively obliges and empowers a child offender to own his or her conduct in a peer context.[30] The offender then shares in his or her own criminal justice by discussing appropriate consequences and fulfilling them as stipulated by the court of peers.[31] If the offender is unwilling to conform to teen court procedures, he or she may have her case referred back to juvenile court.[32]

Teen courts vary in which types of cases are accepted, but most cases are typically first-time offenders of non-violent crimes.[33] Examples of crimes teen courts might see include: "shoplifting, petty theft, underage smoking, truancy, $\ldots$ curfew violations, $\ldots$ underage drinking, $\ldots$ [and] possession of drug paraphernalia."[34] Teen courts function 
in a team approach where the teen offender, prosecutor, defense attorney, jury, and supervising adult together come to a consensus on appropriate consequences.[35] The child offender's input is highly necessary and even esteemed and respected in the teen court model. Under the team-based approach used in teen courts, there are four different court models: adult judge, teen jury model, teen judge panel, and youth judge model.[36] Out of these, the most popular is the adult judge model, utilized by almost half of teen courts.[37] The common theme throughout these different models is peer influence: teens must face the consequences of their actions before a jury of their peers.[38]

Despite opposition from those who consider it dangerous to place upholding the law in the hands of teens, [39] youth courts have seen success in those teens that complete the program. Studies of recidivism rates in teen courts compared to those of traditional juvenile courts reveal a significant drop in recidivism for children who participate in teen courts.[40] Furthermore, studies show that teen courts often serve more harsh punishments for the same charges when compared with typical juvenile court punishments.[41] As youth courts are still a fresh idea in American juvenile justice, however, there is not a great deal of research on these programs. Most of the teen/youth courts are run privately through volunteers, schools, and libraries without resources to do extensive research into program effectiveness, recidivism, or community impact over longer periods of time. [42] As these programs mature and become more are established, continued research into effectiveness of programs and impacts on the traditional juvenile justice system will be most helpful for further examination. As we have illustrated, a good deal of the research available demonstrates that the approach is child-focused and uniquely effective.

\section{Therapeutic Jurisprudence as the Foundation of Teen Courts}

The theory behind therapeutic jurisprudence is to observe antitherapeutic effects of laws and legal processes, analyze what causes those antitherapeutic effects, research social sciences and public policy behind the laws, and creatively converge these findings in hopes of sparking reform in the law to minimize antitherapeutic effects and, where conducive to the legal process, maximize therapeutic effects.[43] Teen courts illustrate therapeutic jurisprudence in both formation and practice. Teen courts were founded by communities experiencing the failure of the American juvenile justice system,[44] designed to achieve the stated goal of rehabilitating offenders and redirecting youth from a life that could be potentially characterized by criminal activity.[45] The traditional juvenile system created an increased risk of abuse, dropping out of school, and further exposure to crime through adult-like prisons, leading to a life characterized by criminal activity and reinvolvement with the criminal justice system.[46] Seeing this disparity in purpose and effects, founders of the teen court movement sought a system that would effectuate rehabilitation of teens, encouraging them to take responsibility by facing the consequences of their actions before their peers, empowering them to participate in their own justice. This is therapeutic jurisprudence in action.

Social science research contributed to the teen court movement as well through studies revealing that the greatest sphere of influence for teens are their peers, making them more likely to change behavior upon facing disapproval from peers than from other authority figures.[47] Seeing this, teen courts implemented a system of peer-accountability, where teens serve as the prosecution, defense, jury, and sometimes judge. Participants must acknowledge their actions before their peers, receiving disapproval for those illegal actions, behaviors and choices from the very people whose affirmation they most seek.

Research has also revealed that teens are less likely to break laws they reasonably understand.[48] Throughout the proceeding, teen jury members and judges consult with the participant, seeking clarification of the facts and reasons why certain actions and decisions were made. By taking the time to investigate actions, observe contributing factors, and explain the reasoning behind the rules, the participant leaves the teen court with a new understanding of the laws broken. This presents a striking difference from the sometimes hasty and superficial proceedings in traditional juvenile courts, which leave a teen offender with lots of consequences and little explanation.[49] In teen courts not only is the offender part of the team that deliberates her case, actively participating in the process of his or her own justice, but the offender has an opportunity to later participate as a jury member in the future stages of the program in hopes each offender will understand and be able to uphold the law moving forward.[50] This process allows the law to work as a therapeutic agent to benefit the child offender, as well as the community in which he or she lives. Graduates of a teen court program are afforded the opportunity of continued involvement with the legal system as jury members, prosecutors, defense attorneys, and, in some cases, even judges.[51]

\section{Developing the Connections between Therapeutic Jurisprudence and Teen Courts}

Therapeutic jurisprudence as a concept was first offered in 1987 by Professor David Wexler in the context of mental health. [52] Wexler defines the idiom as "the study of the role of the law as a therapeutic agent."[53] Integrating human elements with the application of the law, this definition was later refined by Professor Christopher Slobogin to "the use of social science to study the extent to which a legal rule or practice promotes the psychological and physical well-being of the people it affects."[54] With roots in the legal realism movement, therapeutic jurisprudence 
focuses on the emotional and psychological impacts of laws and legal processes.[55] These emotional and psychological impacts can work positively, or therapeutically, towards rehabilitation, or have negative or anti-therapeutic, effects on the offender. Using these therapeutic and anti-therapeutic consequences of the law, therapeutic justice provides a framework by which to analyze and critique laws.[56] Using insights from psychology, psychiatry, clinical behavioral sciences, criminology, and social work, therapeutic jurisprudence integrates these disciplines with the law's consequences, devising new ways, methods, and avenues to provide for a more helpful system.[57] Through this process, therapeutic jurisprudence exposes how laws and legal processes uphold or frustrate the underlying public policy.[58] Outcome-focused, therapeutic jurisprudence considers the legal system's effects and investigates root causes of those effects.[59] Limiting the focus to the problems without investigating root causes, better outcomes, and new ideas would be "seriously shortsighted."[60] Rather than merely providing a way to point out the flaws in laws or legal processes, therapeutic jurisprudence encourages practitioners to seek "convergence of various interests" in finding creative ways to resolve complex issues.[61]

Originating in mental health law reform, therapeutic jurisprudence's debut sought exploration of ways new developments in mental health research might be used in refining the law.[62] Reformation and rehabilitation programs at this time were met with skepticism since laws designed to help people regain or attain mental health often backfired, causing an opposite effect than what was desired.[63] Prior to these new developments, traditional mental health law isolated courts from the expertise of doctors and hospitals which often resulted in an infringement of liberty.[64] When it became evident, however, that social sciences could help bridge the gap between spotting the issues and finding and developing real solutions to those problems, legal scholars began applying the concept to other fields of law.[65] New scholarship then began to take seriously research outcomes in clinical behavioral sciences, contemplating its use in developing legal concepts and practices.[66] Today, using "relevant psychological principles" and social sciences in forming legal doctrine is a standard practice that works to inform the legal process for the benefit of those it serves.[67] After its initial introduction through mental health law, therapeutic jurisprudence has since developed in its application to criminal law, juvenile law, family law, personal injury law, and many other areas. [68] We posit it has had a favorable effect on juvenile justice diversion programs, even if unintentionally, via teen court options for child criminal offenders.

\section{Therapeutic Jurisprudence in Practice through Teen Courts}

Children in any legal context deserve the application of the standard of jurisprudence accommodating what is in the best interests of the child at the center of the litigation. With that standard in mind, teen courts have developed and become almost pervasive throughout America, with many venues developing specialized drug treatment courts, as well as particular problem solving courts.

\section{A. Best Interests of Children}

Therapeutic jurisprudence is useful in analyzing and critiquing the ant-therapeutic effects of an adversary legal system where children are involved. Child custody cases serve as a prime example. In a traditional adversarial system, maintaining relationships between contestants are generally not a priority, but in child custody cases "relationships are at the heart of the matter."[69] Because child custody cases have the responsibility of striking a delicate balance between parental rights and the best interests of a child, one goal of the system is determining and providing for the best interest of the child in light of the parties' considerations; maintaining cooperation for the child's well-being becomes central to the outcome for that child's best interests.[70]

In child custody hearings, however, both parties present their case for a learned judge, who does not know the child, to determine the best interest of the child.[71] Both parties inevitably try to win the battle, breaking down the relationship between parties, leading to harmful effects in the child's relationship with his or her parents.[72] This wrong focus on parental rights can lead to harmful effects on a child's welfare.[73] With an ever increasing number of children involved in custody conflicts, the real danger is rooted in the "chronic conflict" of parents entangling their children and deteriorating the child's parental relationships.[74] Because these ant-therapeutic effects have been observed, efforts are made to move these child custody cases towards a "conciliatory model" that might "honor [these] relationships." [75] The establishment of a guardian ad litem to represent the child's best interests has improved adjudication of custody cases because the interests of the child are represented separately from the parents, assisting judges in determining the child's interests in the midst of parental conflict and emotions.[76] Other suggestions have included creating a "unified family court system," crafting "differentiated case management" in family law, mandating parents create "parenting plans," or establishing a team-based approach of professionals for custody cases.[77] Social science research, indeed, has clearly found that maintaining healthy parental relationships are always in the best interests of the child.[78] American family law has long recognized "that parents are the truest protectors of their child's best interests,"[79] but a therapeutic approach to child custody can also assist in helping divorcing parents to accomplish an outcome in the best interests of the child.

The example from child custody is instructive to juvenile justice. In a similar manner, undergoing a therapeutic jurisprudence analysis of a legal system involving children even where the child is the offender, looks to possible ways to encourage healthy relationships between parents and children for the child's best interest. [80] While our current 
adversarial system needs to look to "a new paradigm, which reflects an attitude of care and shared responsibility toward families and children," [81] teen courts integrate that rationale. While there is ample opportunity for continued research in this area of the law, children are well served by a main focus which maintains for the child strong, healthy and loving parental relationships in pursuing the best interest of the child, particularly when that child is facing the consequences of a criminal offense.

This in turn works with the peer influence advantages of teen courts to develop love and respect that can empower a child toward improved behavior. The two working together courts and parents focused on the child's best interests, and peers focused on positive influence of the child offender can work in concert in a therapeutic manner to empower teens otherwise involved in the judicial system. These principles of therapeutic jurisprudence form the foundation for specialized courts for teens involved in drug offenses in drug treatment courts and other particular problem behaviors in problem-solving courts, as the next sections describe.

\section{B. Drug Treatment Court}

With the expansion of the war on drugs policies at both federal and state levels in the United States in the 1980's came a surge of drug-related offenders in courts, and eventually in prisons, around the country.[82] Many of these offenders were released on parole only to be rearrested on felony charges or new drug offenses within three years.[83] Founded to combat this ever increasing problem of drug abuse, the drug treatment court was founded in Miami in 1989 in response to the "revolving door effect" typical of drug offenders.[84] Looking at the normative processing of nonviolent possession charges in criminal courts and sentencing the offender to prison, it became apparent that this process did nothing to effect change in the behavior of offenders.[85] Children were not exempt from drug abuse and its criminal effects, and drug treatment courts were a perfect remedy for child drug offenders. Acknowledging the physical, psychological, and mental health aspects of drug abuse, drug treatment courts seek a convergence of therapeutic programs of the drug treatment community with traditional practices of the criminal justice system.[86]

At the heart of the drug treatment court concept is integration of the normative judicial process and therapeutic treatment seeking the rehabilitation of offenders.[87] Drug Courts rely on early intervention, as quick interception from the traditional criminal court process and placement in a drug treatment program are the keys to success.[88] In order to participate in the program, however, the offender in most cases must plead guilty.[89] The court conducts regular drug tests, interacts directly with the participant, and participates in participant treatment through a team approach.[90] A typical team consists of "the judge, prosecutor, defense counsel, treatment providers, and community corrections personnel."[91] Reconciliation of the defendant, the community, and the victim(s) is the essential goal of drug treatment courts.[92] Conducted in this manner, teen drug courts provide comprehensive therapeutic solutions to child drug offenses.[93]

Indeed, children involved with drug offenses needed a better method of correction than a single application of justice in a traditional juvenile court. Teen drug treatment courts function on a team-based approach toward rehabilitating the offender to society, providing what a child needs most.[94] Just as they do in a regular teen court, the offender, judge, prosecutor, and defense work together in teen drug courts, focusing on rehabilitation and "law-abiding behavior."[95] In these courts, the judge is active in the offender's treatment program, which contains "clearly defined rules and structured goals" designed to effectuate active offender participation in his or her own rehabilitation.[96] In order to participate in these courts, offenders must agree to several conditions: remaining sober, engaging in a set drug treatment program, agreeing to routine drug tests to track conformity, and appearing in court for judicial oversight of progress.[97] Offenders may be referred to drug treatment courts at any time, and a noncompliant participant may have her case transferred back to the traditional court for further proceedings.[98] This places the responsibility on participants to actively engage in their treatment plan alongside this team of support for rehabilitation.

Drug treatment courts were created expressly to "interrupt the offender's addictive behavior," so the drug court process becomes a component of therapy.[99] In traditional criminal courts, offenders might not have their case heard until months after the initial arrest. Drug treatment courts, however, see importance in immediately involving the participant in the process.[100] The use of drug treatment courts as an alternative to the traditional criminal justice system has been successful in helping offenders break their addiction and avoid recidivism leading to the large growth of these courts across the nation for adults,[101] and in the teen court model.[102] Besides lower recidivism rates, drug treatment courts provide for "more effective case load management, reduced systematic costs" and a reduction in jail crowding.[103] Drug treatment courts exemplify the use of considering advances in social sciences in reforming harmful ant-therapeutic effects of the criminal justice system.[104]

For children, these methods are not simply alternatives or diversion programs, they are absolutely necessary to afford the child offender hope for a drug-free future.

\section{Problem Solving Courts}

Problem solving courts, developed because of breakthroughs in therapeutic jurisprudence, use fundamental aspects of therapeutic jurisprudence to strengthen their impact and performance.[105] Foundational therapeutic jurisprudential ideas, such as including "treatment services with judicial case processing,... multidisciplinary involvement, and collaboration with community-based and governmental organizations," contribute to the development and success of these courts.[106] These courts were founded 
in response to many social and psychological problems appearing throughout the court system, which required the court to "solve a variety of human problems" as well as disputes between parties.[107] Birthed from the methodology of drug treatment courts, [108] problem solving courts were founded in an attempt to assist the parties to effectively address and deal with underlying issues, culminating in creating the opportunity to prevent later issues from the same underlying problem.[109]

The establishment of problem solving courts came from a growing recognition that the traditional procedures in areas of mental health, substance abuse, child abuse and neglect, domestic violence, and "certain kinds of criminality" fall short.[110] Each of these areas contains high recidivism rates indicating that underlying problem(s) in these areas were not properly or effectively addressed.[111] An understanding of therapeutic jurisprudence methods, and the social science principles it uses, aids in the structuring and practice of problem solving courts to better understand and address these underlying problems.[112] This notion works effectively for child offenders, empowering them and their families with an integrated approach to underlying problems. This works to build relational trust and respect between children and their families and others who support them.

Focused on offender rehabilitation through implementation of "treatment and rehabilitative services" overseen by a treatment team,[113] these youth problem solving courts are concerned more with reducing recidivism, or reoccurrence, rather than with merely resolving the surface issues of the case at hand.[114] Judges in problem solving courts, as part of the treatment team, undergo "specialized training" in the specific area to better "function as therapeutic agents through their supervision and monitoring of the offender's treatment progress."[115] The law works as a truly therapeutic agent.

\section{Conclusions}

The development of therapeutic jurisprudence in law and policy combined with the growth in teen courts across the nation are effectuating significant change in the inner workings of the juvenile system. Therapeutic jurisprudence contributes new ideas of integrating therapy and the juvenile legal process through continued research and insights from social sciences.

Teen courts are different from the standard juvenile justice system in that while the juvenile justice system limits an adolescent to a defensive or reactive role within the narrow confines of the legal definition of the crime the adolescent is accused of, the teen court structure empowers the teen offender to grow and be nurtured and rehabilitated through the process. A child's future is imperiled in juvenile court, while the future brings hope in teen court. If the adolescent does not prevail defensively in the traditional system then the court decides what should happen to him or her. That focus is narrow because it does not encourage the teen to think about how his or her conduct has impacted himself, his family, his community. Teen court is much more proactive in the sense that it encourages teens to examine the motivation behind their conduct, to acknowledge the far reaching consequences of that conduct and to participate in framing a response to the conduct that not only makes the teen accountable but on some level mends relationships with family, community and victim.

An emerging model of therapeutic jurisprudence, teen courts make a healthy difference in the lives of child offenders. This creative use of insightful research in the juvenile system creates hope for decreasing the harmful effects of the current juvenile justice system. Through continued research in the outcomes of teen courts, the traditional juvenile system, and social sciences, American juvenile law can continue to advance ways to intercept teens away from a life characterized by criminal activity to redirect their lives by encouraging civic responsibility. The teen court process empowers children with respect from peers, family and community because of the therapeutic manner of administering the law to the child offender. This process becomes a healing model when children's lives are changed by the beneficial involvement of their peers in their legal process. The experience of participating in their own justice and the justice of their peers creates a natural pathway to building a broader sense of personal responsivity, active citizenship, and a generally healthier future.

\section{REFERENCES}

[1] David B. Wexler, Therapeutic Jurisprudence: An Overview, 17 T.M. CoOley L. ReV. 125, 125 (2000).

[2] Peggy Fulton Hora et. al., Therapeutic Jurisprudence and the Drug Treatment Court Movement: Revolutionizing the Criminal Justice System's Response to Drug Abuse and Crime in America, 74 Notre Dame L. ReV. 439, 446 (1999)(quoting Oliver Wendell Holmes).

[3] J. M. Mack, The Juvenile Court, 23 Harvard L. Rev. 120 (1909-10).

[4] Melissa Sickmund, Delinquency cases in juvenile court; Office of Juvenile Justice and Delinquency Prevention, http://www.ncjrs.gov/pdffiles/ojjdp/224538.pdf (accessed Nov. 13, 2013). A legal comparative investigation into the approaches used in juvenile justice around the world would be most helpful to further examine the impact of teen courts and how they integrate therapeutic jurisprudence around the world. That research, however, is beyond the scope of this article.

[5] C. Alfrey, Juvenile delinquency and family structure: implications for marriage and relationship education. National Healthy Marriage Resource Center, www.healthymarriageinfo.org/download.aspz?id=405 (2009); also citing K. L. Kumpher, Strengthening America's families: Exemplary parenting and family strategies for delinquency prevention, CASA, http://www.strengtheningfamilies.org. (Accessed Nov. 13, 2013). 
[6] Melissa Sickmund, Delinquency cases in juvenile court; Office of Juvenile Justice and Delinquency Prevention, http://www.ncjrs.gov/pdffiles/ojjdp/224538.pdf (accessed Nov. 13, 2013).

[7] David B. Wexler, Therapeutic Jurisprudence: An Overview, 17 T.M. Cooley L. Rev. 125, 125 (2000).

[8] D. Williamson, M. Chalk, \& P. Knepper, Teen Court: Juvenile Justice for the $21^{\text {st }}$ Century, Federal Probation 84, at 87 (1993) (challenging the posture and effectiveness of teen courts).

[9] National Association of Youth Courts, Youth Court Functions, http://www.youthcourt.net/?page_id=24 (2013) (hereinafter NAYC).

[10] Ibid. These programs are generally focused on providing community, peer, and family support for the child offender, involving that child centrally in his or her own justice, fostering that child's best interests, and including that child later in the justice process of peers.

[11] S. I. Singer, Criminal and Teen Courts as loosely coupled systems of juvenile justice, 33 Wake Forest L. REV. 509, 527 (1998).

[12] Lynne Marie Kohm, Teen Courts: Empowerment through Child Participation, in International Perspectives and Empirical Findings on Child Participation (Tali Gal and Benedetta Duramy Eds.) (Oxford U. Press 2015), available at https://global.oup.com/academic/product/international-perspe ctives-and-empirical-findings-on-child-participation-9780199 366989? lang $=$ en \&cc $=$ us\#.

[13] Ibid.

[14] Ibid.

[15] See ABA Division for Public Education, The History of Juvenile Justice, Dialogue on Youth and Justice Part One 4 (2013) at http://www.americanbar.org/content/dam/aba/migra ted/publiced/features/DYJpart1.authcheckdam.pdf.

[16] Bruce J. Winick, Therapeutic Jurisprudence and Problem Solving Courts, 30 Fordham Urb. L.J. at 1056.

[17] Youth involved with the Juvenile Justice System, Youth.gov, http://youth.gov/youth-topics/juvenile-justice/youth-involved -juvenile-justice-system\#_ftn6 (accessed Dec. 3, 2015)[hereinafter "Youth involved."]

[18] Ibid. (reporting statistics from Office of Juvenile Justice and Delinquency Prevention (2007)).

[19] Ibid. (reporting numbers from American Correctional Association (2008)).

[20] Ibid. (quoting numbers from Howard N. Snyder and Melissa Sickmund, Juvenile Offenders and Victims: 2006 National Report (2006), at http://files.eric.ed.gov/fulltext/ED495786.p df).

[21] Ibid.

[22] Ibid.

[23] OJJDP Statistical Briefing Book, released Dec. 31, 2015, available athttp://www.ojjdp.gov/ojstatbb/crime/qa05101.asp ?qaDate $=2014$.

[24] National Center for Juvenile Justice and the Office of
Juvenile Justice and Delinquency Prevention, Juvenile Offenders and Victims, 2014 National Report, available at http://www.ojjdp.gov/ojstatbb/nr2014/downloads/NR2014.pd f.

[25] National Center for Juvenile Justice and the Office of Juvenile Justice and Delinquency Prevention, Juvenile Offenders and Victims, 2014 National Report, available at http://www.ojjdp.gov/ojstatbb/nr2014/downloads/NR2014.pd $\mathrm{f}$

[26] See "Youth involved," note 17 (reporting findings from Peter E. Leone, Sheri M. Meisel, and Will Drakeford, Special Education Programs for Youth with Disabilities in Juvenile Corrections, 53 J. OF CORRECTIONAL EDUCATION 46, 46 (2002)).

[27] Ibid. (reporting findings from Andrea J. Sedlak and Karla McPherson, Survey of Youth in Residential Placement: Youth's Needs and Services, SYRP Report (2010), also available at https://www.ncjrs.gov/pdffiles1/ojjdp/grants/227 660.pdf).

[28] Lynne Marie Kohm, Teen Courts: Empowerment through Child Participation, in International Perspectives and Empirical Findings on Child Participation (Tali Gal and Benedetta Duramy Eds.) (Oxford U. Press 2015), available at https://global.oup.com/academic/product/international-perspe ctives-and-empirical-findings-on-child-participation-9780199 366989? lang $=$ en\&cc $=$ us\#

[29] Ibid.

[30] Michele L. George, Teen Court: What All the Hype is About, 27-Oct Colo. LAW. 63 (1998).

[31] Lynne Marie Kohm, Teen Courts: Empowerment through Child Participation, in International Perspectives and Empirical Findings on Child Participation (Tali Gal and Benedetta Duramy Eds.) (Oxford U. Press 2015), available at https://global.oup.com/academic/product/international-perspe ctives-and-empirical-findings-on-child-participation-9780199 366989? lang=en\&cc $=$ us\#.

[32] Jeffrey A. Butts and Jennifer Ortiz, Teen Courts - Do They Work and Why?, 83 N.Y. ST. B.J. 18, 18 (2011); and Dianne Molvig, Justice, Teen Style, 75-AUG Wis. Law. 10, 14 (2002).

[33] Kohm, note 12, at 287; see also Dianne Molvig, Justice, Teen Style, 75-AUG Wis. Law. at 12.

[34] Diane Molvig, Justice Teen Style, 75-AUG Wis. Law. 10, 14 (2002).

[35] Lynne Marie Kohm, Teen Courts: Empowerment through Child Participation, in International Perspectives and Empirical Findings on Child Participation (Tali Gal and Benedetta Duramy Eds.) (Oxford U. Press 2015), available at https://global.oup.com/academic/product/international-perspe ctives-and-empirical-findings-on-child-participation-9780199 366989? lang $=$ en $\& c c=$ us\#.

[36] Ibid.

[37] Ibid.

[38] Diane Molvig, Justice Teen Style, 75-AUG Wis. Law. 10, 13 (2002).

[39] See, e.g. Deborah Fogays and L. DeMilio, Is teen court effective for repeat offenders: A test of the restorative justice 
approach, INT'L J. Offender Therapy \& Comparative Criminology 107, 118 (2005) (discussing concerns over teen court authority and effectiveness).

[40] Lynne Marie Kohm, Teen Courts: Empowerment through Child Participation, in International Perspectives and Empirical Findings on Child Participation (Tali Gal and Benedetta Duramy Eds.) (Oxford U. Press 2015), available at https://global.oup.com/academic/product/international-perspe ctives-and-empirical-findings-on-child-participation-9780199 366989? lang=en\&cc $=$ us\#.

[41] Diane Molvig, Justice Teen Style, 75-AUG Wis. Law 10, 14 (2002).

[42] Lynne Marie Kohm, Teen Courts: Empowerment through Child Participation, in International Perspectives and Empirical Findings on Child Participation (Tali Gal and Benedetta Duramy Eds.) (Oxford U. Press 2015), available at https://global.oup.com/academic/product/international-perspe ctives-and-empirical-findings-on-child-participation-9780199 366989? lang=en\&cc $=$ us\#

[43] See David B. Wexler, Therapeutic Jurisprudence and the Culture of Critique, 10 Contemp. Legal Issues, at 269.

[44] National Association of Youth Courts, Youth Court Functions, http://www.youthcourt.net/?page_id=24 (2013)(hereinafter NAYC).

[45] Lynne Marie Kohm, Teen Courts: Empowerment through Child Participation, in International Perspectives and Empirical Findings on Child Participation (Tali Gal and Benedetta Duramy Eds.) (Oxford U. Press 2015), available at https://global.oup.com/academic/product/international-perspe ctives-and-empirical-findings-on-child-participation-9780199 366989? lang=en\&cc $=$ us\#

[46] Youth involved with the Juvenile Justice System, Youth.gov, http://youth.gov/youth-topics/juvenile-justice/youth-involved -juvenile-justice-system\# ftn6 (accessed Dec. 3, 2015)[hereinafter "Youth involved."]

[47] See Dustin Albert, Jason Chein, and Laurence Stenburg, Peer Influences on Adolescent Decision Making, 22 Curr. Dir. Psychol. Sci. 114 (2013); Chein et. al., Peers Increase Adolescent Risk Taking by Enhancing Activity in the Brain's Reward Circuitry, 14 Developmental Science F1 (2011); Clea McNeely and Jayne Blanchard, The Teen Years Explained: A Guide to Healthy Adolescent Development (2009), at http://www.jhsph.edu/research/centers-and-institut es/center-for-adolescent-health/ includes/ pre-redesign/Inter active\%20Guide.pdf); Jeffrey $\bar{A}$. Butts and Jennifer Ortiz, Teen Courts - Do They Work and Why?, 83 N.Y. ST. B.J. at 20; and see also Molvig, note 28, at 11.

[48] Lynne Marie Kohm, Teen Courts: Empowerment through Child Participation, in International Perspectives and Empirical Findings on Child Participation (Tali Gal and Benedetta Duramy Eds.) (Oxford U. Press 2015), available at https://global.oup.com/academic/product/international-perspe ctives-and-empirical-findings-on-child-participation-9780199 366989? lang $=$ en \&cc $=$ us\#.

[49] See generally Diane Molvig, Justice Teen Style, 75-AUG Wis. Law. 10, 14 (2002).

[50] Lynne Marie Kohm, Teen Courts: Empowerment through Child Participation, in International Perspectives and Empirical Findings on Child Participation (Tali Gal and Benedetta Duramy Eds.) (Oxford U. Press 2015), available at https://global.oup.com/academic/product/international-perspe ctives-and-empirical-findings-on-child-participation-9780199 366989? lang $=$ en $\& \mathrm{cc}=\mathrm{us} \#$.

[51] Diane Molvig, Justice Teen Style, 75-AUG Wis. Law. 10, 14 (2002).

[52] Peggy Fulton Hora et al., Therapeutic Jurisprudence and the Drug Treatment Court Movement: Revolutionizing the Criminal Justice System's Response to Drug Abuse and Crime in America, 74 Notre Dame L. Rev. 439, 442 (1999).

[53] David B. Wexler, Therapeutic Jurisprudence: An Overview, 17 T.M. Cooley L. Rev. 125, 125 (2000).

[54] Hora, note 2, at 443. See also Stephen H. Behnke \& Elyn R. Saks, Therapeutic Jurisprudence: Informed Consent as a Clinical Indication for the Chronically Suicidal Patient with Borderline Personality Disorder, 31 LOY. L.A. L. REV. 945, 945 (1998) (discussing how therapeutic jurisprudence promotes the psychological well-being of society as "a legitimate purpose of the law.")

[55] David B. Wexler, Therapeutic Jurisprudence: An Overview, 17 T.M. Cooley L. Rev. 125, 125 (2000).

[56] Ibid. at 126.

[57] Ibid. at 129.

[58] Peggy Fulton Hora et al., Therapeutic Jurisprudence and the Drug Treatment Court Movement: Revolutionizing the Criminal Justice System's Response to Drug Abuse and Crime in America, 74 Notre Dame L. Rev. 439, 444 (1999).

[59] Ibid. at 447.

[60] David B. Wexler, Therapeutic Jurisprudence: An Overview, 17 T. M. Cooley L. Rev. 125, 129-30 (2000).

[61] Wexler, note 39, at 273; see also Hora, note 50, at 445 (noting that " $[\mathrm{t}]$ herapeutic jurisprudence will generally reveal important and previously unrecognized considerations on legal issues. Inevitably, these issues should be placed into a comprehensive legal equation to balance them with or against the other meaningful and pertinent legal and social values that drive the enactment and enforcement of laws.").

[62] David B. Wexler, Therapeutic Jurisprudence and the Culture of Critique, 10 Contemp. Legal Issues, at 267-68.

[63] David B. Wexler, Therapeutic Jurisprudence: An Overview, 17 T. M. Cooley L. Rev. 125, 128 (2000).

[64] David B. Wexler, Therapeutic Jurisprudence and the Culture of Critique, 10 Contemp. Legal Issues, at 268.

[65] See Ibid. at 265-268 (discussing the change in culture from a problem-focused culture to one that approaches new ideas seeking understanding and further knowledge to be used in problem solving).

[66] David B. Wexler, Therapeutic Jurisprudence and the Culture of Critique, 10 Contemp. Legal Issues, at 268.

[67] David B. Wexler, Therapeutic Jurisprudence and the Culture of Critique, 10 Contemp. Legal Issues, at 271.

[68] David B. Wexler, Therapeutic Jurisprudence: An Overview, 17 T.M. Cooley L. Rev. 125, 128 (2000).

[69] Janet Weinstein, And Never the Twain Shall Meet: The Best 
Interests of Children and the Adversary System, 52 U. MIAMI L. REV. 79, 82-83 (1997).

[70] Linda D. Elrod, Reforming the System to Protect Children in High Conflict Custody Cases, 28 WM. Mitchell L. ReV. 495, 504 (2001).

[71] Ibid. at 372 (discussing the issue of a "child-centered doctrine" in the context of third parties desire custody or "when judges are left on their own to decide the matter").

[72] Janet Weinstein, And Never the Twain Shall Meet: The Best Interests of Children and the Adversary System, 52 U. MIAMI L. REV. 79, 84 (1997).

[73] Ibid. at 88 .

[74] Linda D. Elrod, Reforming the System to Protect Children in High Conflict Custody Cases, 28 WM. Mitchell L. Rev. 495, 496 (2001).

[75] Janet Weinstein, And Never the Twain Shall Meet: The Best Interests of Children and the Adversary System, 52 U. MiAMI L. REV. 79, 83 (1997).

[76] Lynne Marie Kohm, Tracing the Foundations of the Best Interest of the Child Standard in American Jurisprudence, 10 J. L. FAM. StUD. at 374 (also available at http://ssrn.com/abstract=1957143).

[77] Linda D. Elrod, Reforming the System to Protect Children in High Conflict Custody Cases, 28 WM. Mitchell L. Rev. 495, 517-18 (2001).

[78] Janet Weinstein, And Never the Twain Shall Meet: The Best Interests of Children and the Adversary System, 52 U. MiAMI L. REV. 79, 85 (1997).

[79] Lynne Marie Kohm, Tracing the Foundations of the Best Interest of the Child Standard in American Jurisprudence, 10 J. L. FAM. STUD. at 373 (also available at http://ssrn.com/abstract=1957143).

[80] Weinstein, note 65 , at $85-86$ (noting that "[w]e need a system which encourages and assists such [parental] relationships. Professionals from the many disciplines engaged in these areas of work need to help parents do their jobs rather than joining sides in a win-lose battle.").

[81] Janet Weinstein, And Never the Twain Shall Meet: The Best Interests of Children and the Adversary System, 52 U. MIAMI L. REV. 79, 175 (1997).

[82] Peggy Fulton Hora et. al., Therapeutic Jurisprudence and the Drug Treatment Court Movement: Revolutionizing the Criminal Justice System's Response to Drug Abuse and Crime in America, 74 Notre Dame L. ReV. 439, 456 (1999).

[83] Ibid. at 461 (discussing that “... at least half of drug offenders sentenced to probation in state courts are rearrested for felony offenses within three years; a third are arrested for new drug offenses.").

[84] Bruce J. Winick, Therapeutic Jurisprudence and Problem Solving Courts, 30 FordHAM URB. L.J. at 1056.

[85] Ibid. See also Hora, note 2, at 455 (“...putting more and more offenders on probation just perpetuates the problem. The same people are picked up again and again until they end up in the state penitentiary and take up space that should be used for violent offenders."), and Ibid. at 449 ("Criminal justice practitioners have come to realize that incarceration alone does little to break the cycle of drugs and crime and that prison is a scarce resource, best used for individuals who are genuine threats to public safety.").

[86] Peggy Fulton Hora et al., Therapeutic Jurisprudence and the Drug Treatment Court Movement: Revolutionizing the Criminal Justice System's Response to Drug Abuse and Crime in America, 74 Notre DAME L. Rev. 439, 453 (1999).

[87] Ibid.

[88] Peggy Fulton Hora, Drug Treatment Courts in the Twenty-First Century: The Evolution of the Revolution in Problem-Solving Courts, 42 GA. L. REV. 717, 725 (2008).

[89] Peggy Fulton Hora, Drug Treatment Courts in the Twenty-First Century: The Evolution of the Revolution in Problem-Solving Courts, 42 GA. L. REV. 717, 726 (2008).

[90] Ibid.

[91] Ibid.

[92] Peggy Fulton Hora, Drug Treatment Courts in the Twenty-First Century: The Evolution of the Revolution in Problem-Solving Courts, 42 GA. L. REV. 717, 727 (2008).

[93] See, e.g. the Daniel Bryant Teen Court for drug offenses. "Our adolescent treatment services are founded upon an evidence-based curriculum, The Matrix Model for Teens and Young Adults, that gives young clients the knowledge, structure, and support to evaluate the significance of their drug and alcohol use, move them to a place of abstinence, and provide support for sustained recovery. Treatment consists of group counseling, drug testing, and individual crisis counseling as needed." Daniel Bryant Youth and Family Treatment Center, Council on Alcoholism and Drug Abuse,

http://cadasb.org/youth-services/daniel-bryant-treatment-cent er.aspx (2014).

[94] Peggy Fulton Hora et al., Therapeutic Jurisprudence and the Drug Treatment Court Movement: Revolutionizing the Criminal Justice System's Response to Drug Abuse and Crime in America, 74 Notre Dame L. Rev. 439, 453 (1999).

[95] Ibid. at 469.

[96] Ibid. See also Winick, note 16, at 1056-57. "Instead of relying on the traditional criminal justice approach, the drug treatment court emphasized the offender's rehabilitation, and placed the judge as a member of the treatment team." Ibid.

[97] Bruce J. Winick, Therapeutic Jurisprudence and Problem Solving Courts, 30 FordHAM URB. L.J. at 1057.

[98] Peggy Fulton Hora et al., Therapeutic Jurisprudence and the Drug Treatment Court Movement: Revolutionizing the Criminal Justice System's Response to Drug Abuse and Crime in America, 74 Notre Dame L. Rev. 439, 470 (1999).

[99] Ibid. at 473.

[100] Ibid. (discussing the importance of "intervention when he or she is in crisis."). Some participants are able to start treatment just two days after the initial arrest. Ibid.

[101] Ibid. at 454.

[102] See, e.g. the Daniel Bryant Teen Court for drug offenses. "Our adolescent treatment services are founded upon an evidence-based curriculum, The Matrix Model for Teens and Young Adults, that gives young clients the knowledge, 
structure, and support to evaluate the significance of their drug and alcohol use, move them to a place of abstinence, and provide support for sustained recovery. Treatment consists of group counseling, drug testing, and individual crisis counseling as needed." Daniel Bryant Youth and Family Treatment Center, Council on Alcoholism and Drug Abuse,http://cadasb.org/youth-services/daniel-bryant-treatme nt-center.aspx (2014).

[103] Peggy Fulton Hora et al., Therapeutic Jurisprudence and the Drug Treatment Court Movement: Revolutionizing the Criminal Justice System's Response to Drug Abuse and Crime in America, 74 Notre Dame L. ReV. 439, 456 (1999).

[104] Peggy Fulton Hora et al., Therapeutic Jurisprudence and the Drug Treatment Court Movement: Revolutionizing the Criminal Justice System's Response to Drug Abuse and Crime in America, 74 Notre Dame L. Rev. 439, 445 (1999).

[105] Winick, note 16, at 1064 (discussing that problem solving courts and therapeutic jurisprudence developed at the same time with "similar aims.").

[106] Ibid. (quoting Conference of Chief Justices \& Conference of State Court Admr'rs, CCJ Resolution 22 \& COSCA Resolution 4: In Support of Problem-Solving Courts (2002), a thttp://cosca.ncsc.org/ /media/Microsites/Files/COSCA/Pol icy\%20Papers/Resolution-Natl\%20Agenda-Final-Aug-04.ash $\mathrm{x})$.
[107] Bruce J. Winick, Therapeutic Jurisprudence and Problem Solving Courts, 30 Fordham URB. L.J. at 1055.

[108] Bruce J. Winick, Therapeutic Jurisprudence and Problem Solving Courts, 30 FordHAM URB. L.J. at 1062.

[109] Ibid. ("These newer courts, however, attempt to understand and address the underling problem that is responsible for the immediate dispute, and to help the individuals before the court to effectively deal with the problem in ways that will prevent recurring court involvement.").

[110] Bruce J. Winick, Therapeutic Jurisprudence and Problem Solving Courts, 30 Fordham URB. L.J. at 1060.

[111] Ibid.

[112] Bruce J. Winick, Therapeutic Jurisprudence and Problem Solving Courts, 30 FordHAM URB. L.J. at 1066.

[113] See Ibid. at 1065 (discussing the main goal of problem solving courts and the strategies to achieve that goal).

[114] Bruce J. Winick, Therapeutic Jurisprudence and Problem Solving Courts, 30 FordHAM URB. L.J. at 1060.

[115] Id. at 1065 (identifying "the nature and treatment of drug addiction, domestic violence, and mental illness" as areas judges receive specialized training). 